\title{
ANALISIS POLA DISPERSI PARTIKULAT DAN SULFURDIOKSIDA MENGGUNAKAN MODEL WRFCHEM DI SEKITAR WILAYAH INDUSTRI TANGERANG DAN JAKARTA (Analysis of Particulate and Sulfurdioxide Pattern Dispersion using WRFChem Model over Industrial Area In Tangerang and Jakarta)
}

\author{
Ana Turyanti ${ }^{1 *}$, Tania June ${ }^{2}$, Edvin Aldrian ${ }^{3}$ dan Erliza Noor ${ }^{4}$ \\ ${ }^{1}$ Program Studi Pengelolaan Sumberdaya Alam dan Lingkungan, Sekolah Pascasarjana, \\ Institut Pertanian Bogor, Bogor, 16680. \\ ${ }^{2}$ Departemen Geofisika dan Meteorologi, Fakultas Matematika dan Ilmu Pengetahuan Alam, \\ Institut Pertanian Bogor, Bogor, 16680. \\ ${ }^{3}$ Pusat Penelitian dan Pengembangan, Badan Meteorologi Klimatologi dan Geofisika, \\ Kemayoran, Jakarta Pusat, 10720. \\ ${ }^{4}$ Departemen Teknologi Industri Pertanian, Fakultas Teknologi Pertanian, \\ Institut Pertanian Bogor, Bogor, 16680.
}

*Penulis korespondensi. Tel: 081311106882. Email: aturyanti@gmail.com.

Diterima: 15 Oktober 2015

Disetujui: 28 Januari 2016

\begin{abstract}
Abstrak
Peningkatan aktivitas industri dan transportasi menjadi pemicu timbulnya potensi pencemaran udara yang berdampak pada kesehatan masyarakat, terutama di sekitar wilayah industri dan kota-kota besar. Pengenalan daerah yang rawan terhadap pemaparan konsentrasi pencemar udara maksimum perlu dilakukan untuk mengantisipasi dampak terhadap kesehatan masyarakat dan lingkungan. Studi ini bertujuan untuk menganalisis sebaran pencemar udara di sekitar wilayah industri dan menentukan lokasi yang berpotensi terpapar pencemar udara dengan konsentrasi maksimum, khususnya partikulat (dalam hal ini $\left.\mathrm{PM}_{10}\right)$ dan sulfurdioksida $\left(\mathrm{SO}_{2}\right)$. Lokasi studi adalah wilayah Jakarta dan Tangerang, yang merupakan daerah padat transportasi juga industri. Analisis dispersi menggunakan model Weather Research Forecasting / Chemistry (WRFChem) dengan ukuran grid 4 x 4 km, selama periode 5 hari (120 jam) masing-masing pada bulan Agustus dan Desember. Hasil analisis model menunjukkan lokasi yang rawan terpapar pencemar $\mathrm{PM}_{10}$ maupun $\mathrm{SO}_{2}$ dengan konsentrasi maksimum adalah Jakarta Pusat dan Jakarta Utara, secara umum terjadi pada tengah malam hingga pagi hari. Pada siang hari konsentrasi maksimum cenderung terjadi di sekitar Jakarta Selatan, Tangerang Selatan, serta Kabupaten Tangerang. Secara temporal terjadi fluktuasi konsentrasi pencemar udara, konsentrasi siang hari rendah dan meningkat menjelang malam hari hingga dini hari. Faktor meteorologi terutama pola angin sangat mempengaruhi pola sebaran pencemar di wilayah studi, dan keberadaan garis pantai juga mempengaruhi terakumulasinya pencemar di sekitar wilayah Jakarta.
\end{abstract}

Kata kunci: konsentrasi maksimum, kualitas udara, partikulat, pola angin, sebaran pencemar udara, sulfurdioksida.

\begin{abstract}
Increasing industrial and transportation activity were associated with air pollution, especially in urban and industrial area. The air pollution is associated with significant adverse health effects. Understanding the potential implications of the air pollution to human health, developing strategies to mitigate the pollution should be seen as a serious attention. The purpose of this study was to analyze air pollutant dispersion within industrial area and to determine the locations that potentially exposed to maximum pollutant concentrations, especially $\mathrm{PM}_{10}$ and $\mathrm{SO}_{2}$. The evaluation was conducted within Jakarta and Tangerang using a well known modelling tool 'WRFChem'. The WRFChem was simulated for the period of 5 days (120 hours) in August and December using the grid size of $4 \mathrm{~km} x 4 \mathrm{~km}$. The model shows that the maximum concentrations of $\mathrm{PM}_{10}$ and $\mathrm{SO}_{2}$ occurred within Central Jakarta and the North Jakarta, frequently found from the midnight to morning. While during the day time, the maximum concentration tend to occur within the region of South Jakarta, South Tangerang, and Tangerang Regency. Diurnal fluctuation shows the pollutant concentrations are increased at night and decreased after sunrise. Meteorological factors, mainly wind direction, affects the pollutants dispersion in the area of study, and the existence of the shoreline also affects pollutants accumulation around Central Jakarta.
\end{abstract}

Keywords: air pollutant dispersion, air quality, maximum concentration, particulate, sulfurdioxide, wind pattern. 


\section{PENDAHULUAN}

Peningkatan pembangunan dan perekonomian akan memicu peningkatan aktivitas industri dan transportasi. Resiko yang timbul adalah potensi peningkatan konsentrasi pencemar di udara. Pencemaran udara memiliki dampak terhadap kesehatan terutama gangguan pada saluran pernapasan, penyakit jantung, tekanan darah tinggi, stroke, kanker berbagai organ tubuh, gangguan reproduksi bahkan kematian (Anonim, 1998; Anonim, 2001; Anonim, 2006; Arifin dan Sutomo, 2003; Lippmann dan Ito, 2006; Tseng dkk., 2012; Orru dkk., 2009; Ranzi dkk. 2011; Lopez-Cima dkk. 2011; Bacarelli dkk 2011).

Pengelolaan serta pengendalian pencemaran udara sangat diperlukan agar dampak pencemaran udara tidak terlalu parah. Salah satu yang dapat dilakukan adalah dengan mengenali daerah-daerah yang rawan terhadap pemaparan konsentrasi pencemar yang maksimum, terutama di wilayah yang padat industri dan transportasi. Beberapa penelitian terkait dispersi pencemar udara, menunjukkan bahwa akan ada beberapa lokasi di sekitar sumber pencemar yang beresiko terpapar pencemar dalam konsentrasi tertentu (Ruhiyat, 2009; Ranzi dkk., 2011; Lopez-Cima dkk., 2011; Bacarelli dkk., 2011). Walaupun konsentrasi tersebut berfluktuasi, tetapi jika arah angin dominan menuju ke wilayah tersebut, akan terjadi akumulasi pencemar, sehingga berpotensi melampaui baku mutu udara ambien, dan resiko keterpaparan dalam waktu lama akan mengancam kesehatan masyarakat di sekitar lokasi tersebut. Finn dkk (2010) menyarankan fluktuasi konsentrasi maksimum harus dipertimbangkan sebagai faktor penting dalam menentukan resiko keterpaparan, karena potensi dampak zat berbahaya serta respon toksisitas akut oleh pajanan jangka pendek ditentukan oleh konsentrasi maksimum.

Emisi pencemar udara akan tersebar sesuai kondisi meteorologi setempat terutama arah angin rata-rata dan fluktuasi kecepatan turbulen, serta stabilitas atmosfer yang sangat dinamis baik temporal maupun spasial (Oke, 1986; Nasstrom dkk., 2000; Stroh dkk., 2005). Perbedaan stabilitas atmosfer urban cukup kontras terjadi pada siang dan malam hari, sehingga akan mempengaruhi pola dispersi pencemar secara diurnal (Finn dkk., 2010).

Pemodelan dispersi pencemar menjadi salah satu pilihan untuk mempelajari pola sebaran pencemar. Weather Research Forecasting / Chemistry (WRFChem) merupakan salah satu model yang sudah menggabungkan model meteorologi dengan model kualitas udara (Yerramilli dkk., 2008; Zhang dkk., 2009; Tucella dkk., 2012; Baklanov dkk., 2014), yang memungkinkan untuk menduga komponen meteorologi dan kimia secara simultan atau disebut juga online couple. Model memperhitungkan proses kimia dan fisika atmosfer yang saling mempengaruhi, sehingga diharapkan proses transport maupun transformasi kimia pencemar lebih terakomodasi dalam pemodelan (Grell dkk., 2005; Grell dan Baklanov, 2011). Model dispersi pencemar udara yang banyak digunakan di Indonesia adalah model dengan pendekatan dispersi Gauss (Rahmawati, 2003; Hadibowo dan Huboyo, 2006; Warlina 2008; Ruhiyat 2009), oleh karena itu penggunaan model WRFChem di wilayah Indonesia perlu dipelajari.

Jakarta dan Tangerang merupakan wilayah yang sangat padat aktivitas transportasi sekaligus memiliki beberapa wilayah yang padat industri, menarik untuk dikaji potensi keterpaparannya terhadap pencemar udara khususnya $\mathrm{SO}_{2}$ dan partikulat. Kajian terkait sebaran pencemar terutama $\mathrm{PM}_{10}$ dan $\mathrm{SO}_{2}$ di wilayah tersebut, khususnya yang menggunakan pemodelan belum ada. Bahkan pengamatan kontinu kualitas udara ambien di Kabupaten Tangerang belum dilakukan, sehingga kebutuhan untuk menganalisis kualitas udara melalui pemodelan menjadi penting. Tujuan penelitian ini adalah menganalisis sebaran pencemar udara di sekitar wilayah industri dan menentukan lokasi-lokasi yang berpotensi terpapar $\mathrm{PM}_{10}$ dan $\mathrm{SO}_{2}$ dengan konsentrasi maksimum menggunakan model WRF/Chem.

\section{METODE PENELITIAN}

\section{Waktu dan Lokasi}

Periode pemodelan dilakukan pada 2 musim yaitu musim kemarau diwakili oleh bulan Agustus 2014 dan musim hujan diwakili bulan Desember 2014. Pada bulan Agustus diambil 5 hari yaitu tanggal 12 - 17 Agustus, sedangkan untuk Desember diambil 5 hari yaitu tanggal 24 - 29 Desember. Lokasi penelitian sebagai studi kasus adalah wilayah Jakarta dan Kabupaten Tangerang (Gambar 1).

\section{Prosedur \\ Analisis dispersi menggunakan model WRFChem}

Penelitian ini menggunakan pemodelan meteorologi dan kualitas udara yang terintegrasi yaitu WRFChem. Data yang digunakan adalah data meteorologi global dari National Oceanic Atmospheric Administration (NOAA) periode 12-17 Agustus 2014 dan 24-29 Desember 2014, data emisi global dari Emission Database for Global Atmospheric Research (EDGAR).

Model WRFChem terdiri dari 3 tahap utama, yaitu tahap pre-processing menggunakan program WRF Prepocessing System (WPS), kemudian tahap 


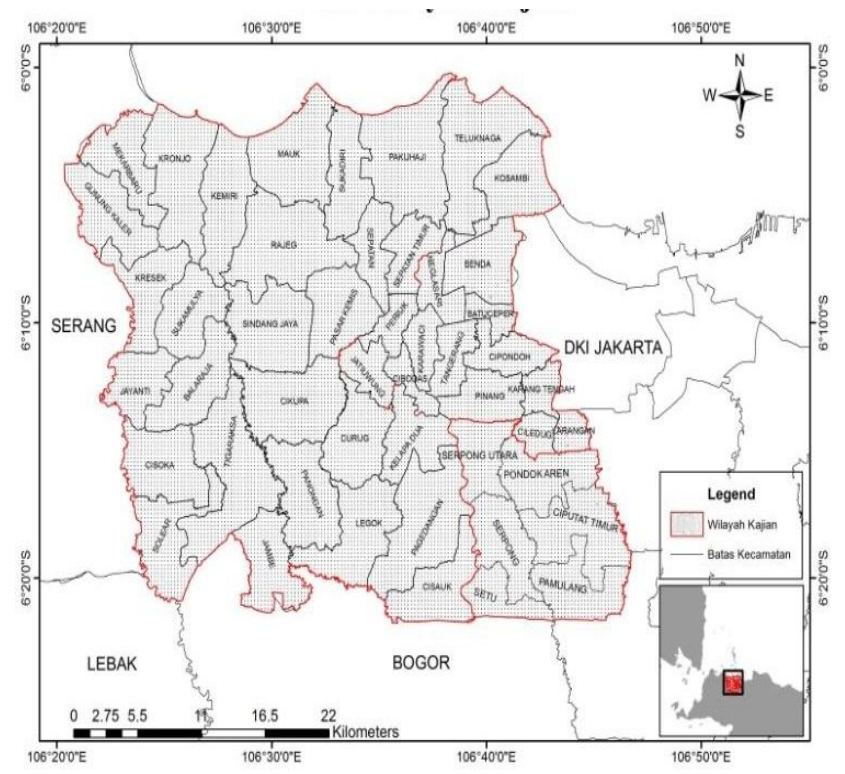

Gambar 1. Lokasi studi.

analisis meteorologi dan kimia atmosfer menggunakan Weather Research Forecasting (WRFV3) dan terakhir tahap pos-processing menggunakan program ARWpost. WPS adalah tahapan untuk mengolah kondisi awal wilayah penelitian yaitu menentukan lokasi koordinat wilayah (domain), batas, ukuran dan resolusi yang digunakan, serta periode waktu model tersebut dijalankan. Pada studi ini domain yang dianalisis adalah $5,43-7,56^{\circ} \mathrm{LS}$ dan $105,196-107,804^{\circ} \mathrm{BT}$, meliputi wilayah Banten dan DKI Jakarta dengan ukuran grid 4 x $4 \mathrm{~km}$. Periode waktu pemodelan masing-masing 120 jam pada musim kemarau dan musim hujan. Output program WPS menjadi input untuk pengolahan meteorologi selanjutnya dalam WRFV3, sekaligus pada program ini dimasukkan input awal kondisi emisi global yang dijadikan dasar pendugaan sebaran pencemar yang dimaksud. Pada tahap ini dilakukan pemilihan parameter-parameter fisik dan kimia lapisan perbatas, yang berperan dalam proses-proses di atmosfer, meliputi proses mikrofisik, proses radiasi, skema fotolisis, mekanisme fase gas dan sebagainya (Grell dkk., 2005; Anonim, 2014). Pengolahan post-processing dengan ARWpost menghasilkan satu file luaran yang dianalisis secara visual maupun angka melalui program Grads.

\section{Analisis Data \\ Validasi model.}

Data yang dianalisis adalah pencemar $\mathrm{PM}_{10}$ dan $\mathrm{SO}_{2}$ sebagai pencemar utama di wilayah industri dan urban. Berhubung Badan Lingkungan Hidup (BLH) Kabupaten Tangerang belum memiliki data pengukuran yang kontinu, maka sebagai pembanding digunakan data pengamatan dari 5 Stasiun Pemantauan Kualitas Udara Ambien milik BPLHD Daerah Khusus Ibukota (DKI) Jakarta tahun
2014, yang masih berada di wilayah kajian. Kelima stasiun tersebut adalah DKI1 sekitar Bundaran Hotel Indonesia (BHI, mewakili Jakarta Pusat), DKI2 sekitar Kelapa Gading (Jakarta Utara), DKI3 daerah Jagakarsa (Jakarta Selatan), DKI4 sekitar daerah Lubang Buaya (Jakarta Timur) dan DKI5 sekitar Kebun Jeruk (Jakarta Barat). Data observasi dari stasiun pengamatan dibandingkan dengan data luaran model pada koordinat yang sama. Adapun jenis data yang dibandingkan adalah data per jam, data rata-rata diurnal per jam selama 5 hari pemodelan serta rata-rata diurnal perjam selama bulan berjalan. Kedekatan pola fluktuasi antara kedua kelompok data dianalisis menggunakan analisis korelasi.

\section{Analisis peta sebaran pencemar secara visual.}

Analisis ini dilakukan untuk melihat lokasilokasi yang berpotensi terpapar $\mathrm{PM}_{0}$ dan $\mathrm{SO}_{2}$ dengan konsentrasi maksimum.

\section{HASIL DAN PEMBAHASAN}

Analisis korelasi menunjukkan nilai koefisien korelasi data per jam $\mathrm{PM}_{10}$ luaran model dengan observasi masih rendah sekitar $r=0,34$. Hal ini didukung oleh beberapa penelitian lain, yang menyimpulkan bahwa konsentrasi hasil model WRFChem untuk aerosol, PM2,5 dan PM10 cukup kecil dan masih underestimate 20-50\%, dibandingkan hasil observasi (Tucella, dkk., 2012; Heriyanto, dkk., 2014; Liao, dkk., 2014; Forkel, dkk., 2015).

\section{Pola Diurnal Konsentrasi Partikulat ( $\left.\mathbf{P M}_{10}\right)$}

Pola umum fluktuasi diurnal konsentrasi $\mathrm{PM}_{10}$ pada bulan Agustus maupun Desember baik data observasi maupun hasil model menunjukkan terjadi peningkatan konsentrasi menjelang malam hingga mencapai maksimum menjelang dini hari. Walaupun demikian besaran rata-rata konsentrasi pada bulan Desember relatif lebih rendah. Menurut Pernigotti dkk. (2007), puncak konsentrasi $\mathrm{PM}_{10}$ terjadi pada malam hari seiring dengan menguatnya stabilitas atmosfer. Konsentrasi $\mathrm{PM}_{10}$ menurun pada siang hingga sore hari seiring perubahan stabilitas atmosfer menjadi tidak stabil. Kecepatan angin yang meningkat di permukaan lebih dari $3 \mathrm{~m}$ det $^{-1}$ akan membantu proses pengenceran sehingga konsentrasi dapat menurun (Sansone, 2006; Pernigotti dkk., 2007). Pada hasil observasi tampak peningkatan konsentrasi pada pukul 8.00-9.00 pagi, berkaitan dengan jumlah emisi kendaraan bermotor pada jam kerja, serta kemungkinan masuknya pencemar dari wilayah lain atau dikenal sebagai long-range transport (Gupta dan Mohan, 2013). Pola diurnal konsentrasi pencemar di masing-masing lokasi 
memiliki karakteristik sendiri, sesuai kondisi lokal wilayah observasi. Koefisien korelasi dicantumkan pada Tabel 1 dan 2. Penelitian Heriyanto dkk. (2014) menunjukkan koefisien korelasi besaran konsentrasi luaran model dengan data observasi di wilayah Jakarta, masih cukup kecil. Gambar 2 menunjukkan fluktuasi konsentrasi di DKI1 bulan Agustus dan Desember.

\section{Pola Diurnal Konsentrasi Sulfurdioksida $\left(\mathrm{SO}_{2}\right)$}

Pola diurnal konsentrasi $\mathrm{SO}_{2}$ pada bulan Agustus memiliki puncak pada dini hari sekitar pukul 02.00 -05.00 (Gambar 3 (a)). Namun pada bulan Desember berbeda, karena pengaruh curah hujan di musim hujan dapat membantu pencucian pencemar dari udara (Gambar 3 (b)). Konsentrasi
$\mathrm{SO}_{2}$ maksimum hasil observasi pada musim kemarau maupun musim hujan terjadi di Kelapa Gading Jakarta Utara, sedangkan minimum terdapat di lokasi Kebon Jeruk. Selain itu konsentrasi berkaitan erat dengan sumber emisi. Pada saat pagi hari konsentrasi $\mathrm{SO}_{2}$ di permukaan rendah, dan seiring dengan bertambahnya aktivitas kendaraan bermotor maka konsentrasi $\mathrm{SO}_{2}$ meningkat. Hal ini dapat menjelaskan adanya peningkatan konsentrasi observasi pada pukul 7.00-9.00 di permukaan. Koefisien korelasi (Tabel 3) menjadi kecil karena pola fluktuasi yang kurang bersesuaian. Hasil pemodelan WRFChem bulan Desember menunjukkan bahwa konsentrasi $\mathrm{SO}_{2}$ menurun mulai pukul 10.00 pagi hingga sore sekitar pukul 17.00 .

Tabel 1. Koefisien korelasi pola diurnal PM $\mathrm{PM}_{10}$ luaran WRFChem dengan data observasi bulan Agustus 2014.

\begin{tabular}{lccc}
\hline Lokasi & \multicolumn{3}{c}{ Koefisien korelasi luaran WRFChem } \\
\cline { 2 - 4 } & Rataan obs 5 hari & Rataan obs bulan Agustus & Rataan obs 1 thn \\
\hline DKI1 & 0,70 & 0,77 & 0,80 \\
DKI2 & 0,48 & 0,62 & 0,68 \\
DKI3 & $-0,11$ & $-0,60$ & 0,51 \\
DKI4 & 0,28 & 0,38 & 0,73 \\
DKI5 & 0,71 & 0,32 & 0,77 \\
\hline
\end{tabular}

Sumber : Data analisis.

Tabel 2. Koefisien korelasi pola diurnal $\mathrm{PM}_{10}$ luaran WRFChem dengan data observasi bulan Desember 2014.

\begin{tabular}{lccc}
\hline Lokasi & \multicolumn{3}{c}{ Koefisien korelasi luaran WRFChem } \\
\cline { 2 - 4 } & Rataan obs 5 hari & Rataan obs bulan Desember & Rataan obs 1 thn \\
\hline DKI1 & 0,38 & 0,78 & 0,52 \\
DKI2 & $-0,14$ & $-0,39$ & $-0,39$ \\
DKI3 & $-0,36$ & $-0,44$ & $-0,34$ \\
DKI4 & $-0,69$ & $-0,48$ & 0,61 \\
DKI5 & $-0,26$ & 0,41 & 0,83 \\
\hline
\end{tabular}

Sumber : Data analisis.

Tabel 3. Koefisien korelasi pola diurnal $\mathrm{SO}_{2}$ luaran model dengan data observasi bulan Agustus 2014 .

\begin{tabular}{lccc}
\hline \multirow{2}{*}{ Lokasi } & \multicolumn{3}{c}{ Koefisien korelasi luaran WRFChem } \\
\cline { 2 - 4 } & Rataan obs 5 hari & Rataan obs bulan Agustus & Rataan obs 1 thn \\
\hline DKI1 & $-0,26$ & $-0,04$ & $-0,01$ \\
DKI2 & 0,43 & 0,70 & 0,53 \\
DKI3 & $-0,75$ & $-0,78$ & $-0,78$ \\
DKI4 & $-0,51$ & $-0,55$ & $-0,66$ \\
DKI5 & $-0,61$ & $-0,50$ & $-0,46$ \\
\hline
\end{tabular}

Sumber : Data analisis.

Tabel 4. Koefisien korelasi pola diurnal $\mathrm{SO}_{2}$ luaran model dengan data observasi bulan Desember 2014.

\begin{tabular}{lccc}
\hline \multirow{2}{*}{ Lokasi } & \multicolumn{3}{c}{ Koefisien korelasi luaran WRFChem } \\
\cline { 2 - 4 } & Rataan obs 5 hari & Rataan obs bulan Desember & Rataan obs 1 thn \\
\hline DKI1 & 0,28 & $-0,54$ & 0,02 \\
DKI2 & $-0,01$ & 0,14 & 0,52 \\
DKI3 & $-0,31$ & $-0,54$ & $-0,66$ \\
DKI4 & $-0,37$ & $-0,64$ & $-0,46$ \\
DKI5 & $-0,24$ & 0,03 & $-0,35$ \\
\hline
\end{tabular}

Sumber : Data analisis. 


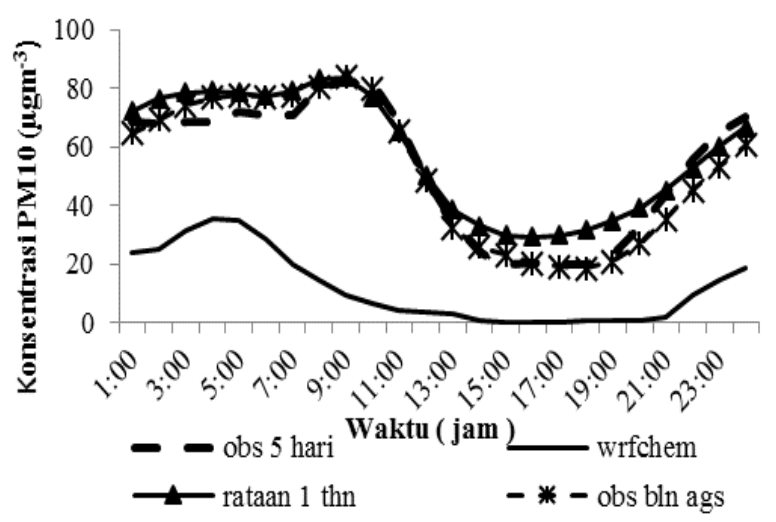

(a)

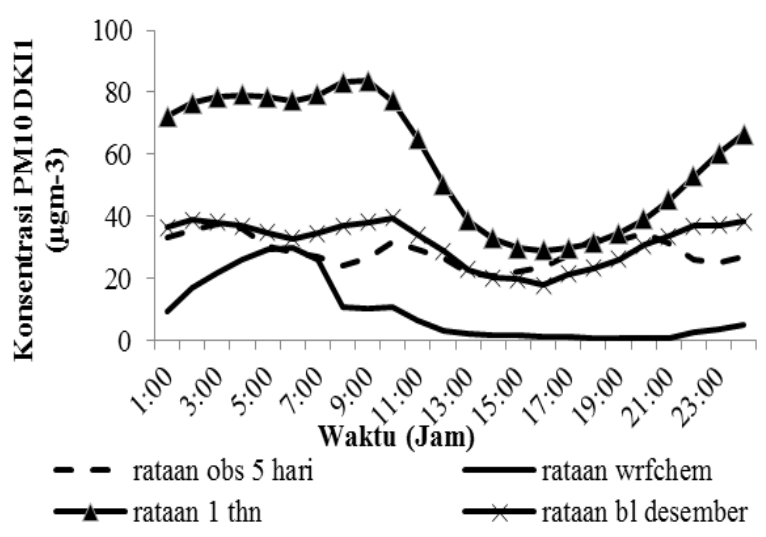

(b)

Gambar 2. Fluktuasi konsentrasi PM10 bulan (a) Agustus (b) Desember 2014 di DKI1.

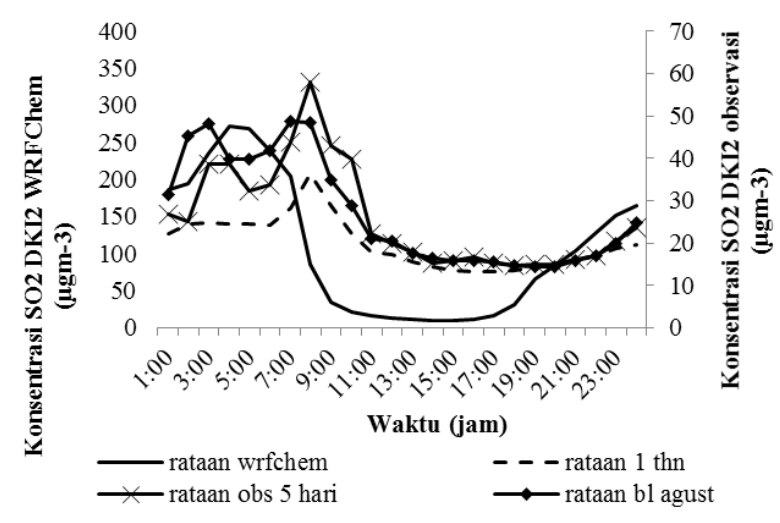

(a)

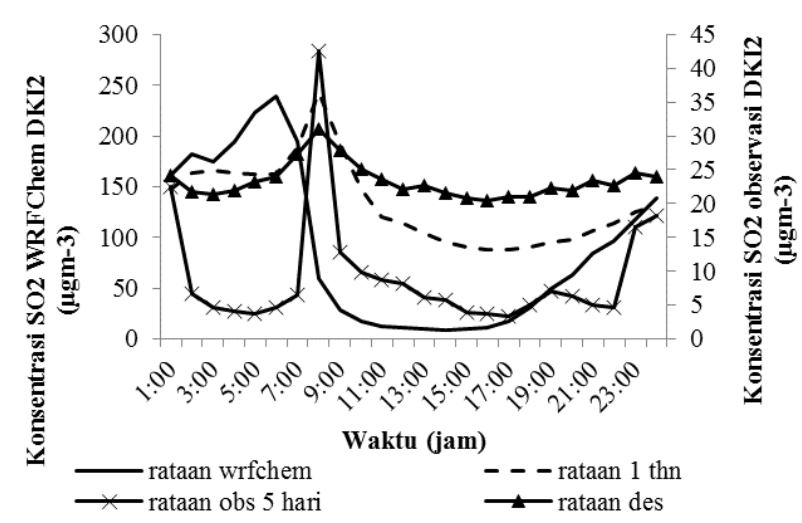

(b)

Gambar 3. Pola fluktuasi konsentrasi $\mathrm{SO}_{2}$ bulan (a) Agustus dan (b) Desember 2014.

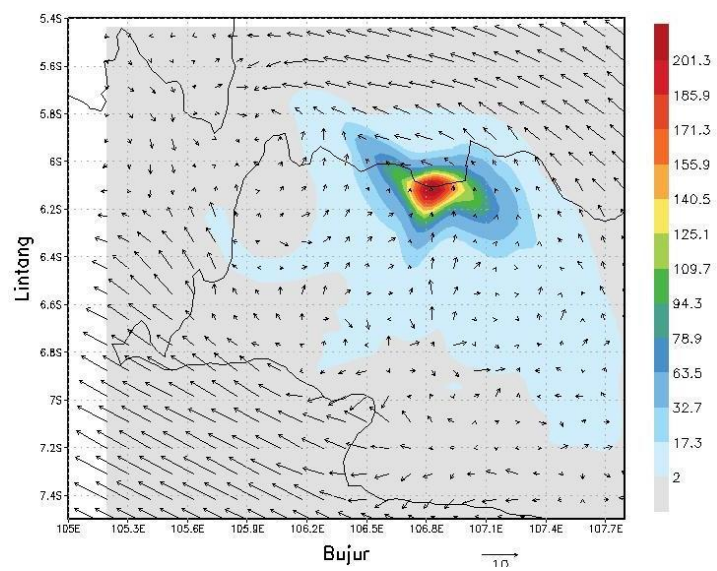

(a)

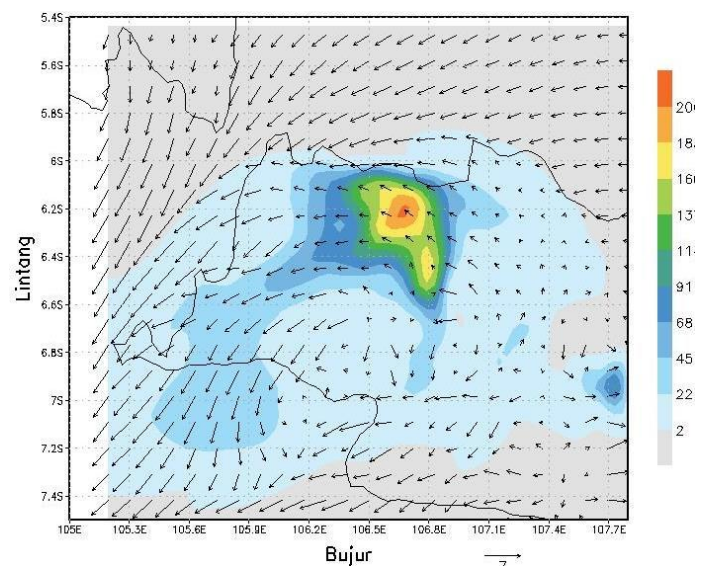

(b)

Gambar 4. Sebaran konsentrasi PM10 bulan (a) Agustus dan (b) Desember tahun 2014.

\section{Analisis Spasial $\mathbf{P M}_{10}$ dan $\mathrm{SO}_{2}$ Luaran Model WRFChem}

Hasil analisis model menunjukkan perbedaan pola sebaran pencemar $\mathrm{PM}_{10}$ dan $\mathrm{SO}_{2}$ dari waktu ke waktu pada musim kemarau dan musim hujan. Lokasi-lokasi dengan konsentrasi pencemar maksimum didapatkan pada setiap jam, sehingga dapat dianalisis waktu dan lokasi yang rawan terpapar konsentrasi maskimum $\mathrm{PM}_{10}$ dan $\mathrm{SO}_{2}$.

\section{Pola Sebaran Partikulat (PM $\mathbf{P M}_{10}$}

Luaran model WRFChem menunjukkan bahwa pola diurnal sebaran pencemar $\mathrm{PM}_{10}$ sangat dipengaruhi oleh pola angin, yang dipengaruhi oleh kondisi topografi serta posisi darat dan laut. Pada sore hari angin dari lereng Gunung Salak di Bogor turun dan menuju ke arah laut, melalui Jakarta, membawa serta material yang terkandung di udara termasuk pencemar. Pada malam hari angin darat membawa pencemar menuju ke arah laut. Pada pagi 
hari pencemar tidak langsung terbawa ke arah laut, karena seiring radiasi matahari meningkat angin laut mulai mendominasi dan bertiup dari laut ke darat. Hal tersebut membuat wilayah DKI Jakarta menjadi wilayah yang berpotensi terpapar pencemar $\mathrm{PM}_{10}$ dengan konsentrasi maksimum baik pada musim kemarau maupun musim hujan Gambar 4.

Hasil running model pada bulan Agustus memberi gambaran pola pergerakan pencemar yang mengikuti pola angin setempat. Lokasi dengan konsentrasi $\mathrm{PM}_{10}$ maksimum pada siang hari berada sekitar Tangerang Selatan (Gambar 5(a)). Malam hingga menjelang pagi konsentrasi maksimum $\mathrm{PM}_{10}$ terjadi di wilayah DKI Jakarta (Gambar 5(b)). Pada malam hari lokasi yang berpotensi terpapar $\mathrm{PM}_{10}$ dengan konsentrasi maksimum adalah daerah Jakarta Pusat memanjang hingga Jakarta Timur. Menjelang pagi konsentrasi tertinggi terjadi jam 05.00 pagi, sebesar $200 \mu \mathrm{g} . \mathrm{m}^{3}$, yaitu di sekitar wilayah Jakarta Pusat hingga ke Jakarta Utara. Nilai ini melebihi nilai Baku Mutu kualitas udara ambien nasional 24 jam sebesar $150 \mu . \mathrm{m}^{-3}$.

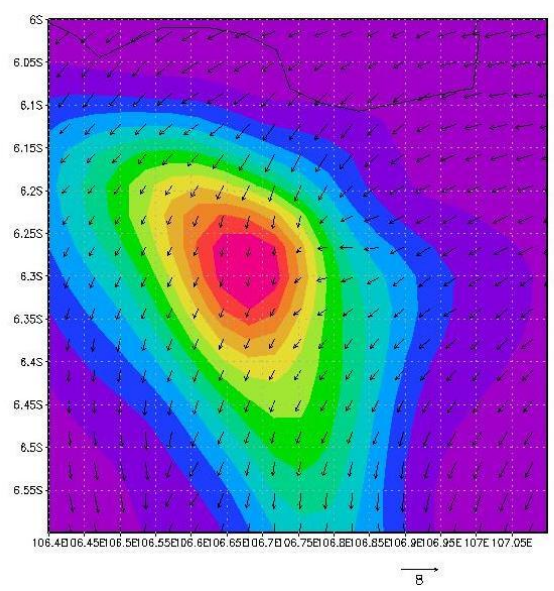

(a)

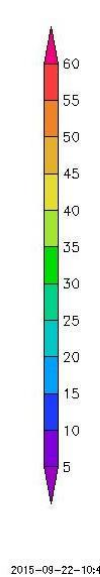

2015-09-22-10:4

Gambar 5. Pola dispersi spasial $\mathrm{PM}_{10}$ bulan Agustus 2014 pada (a) pk 11.00 WIB dan (b) pk 05.00 WIB.

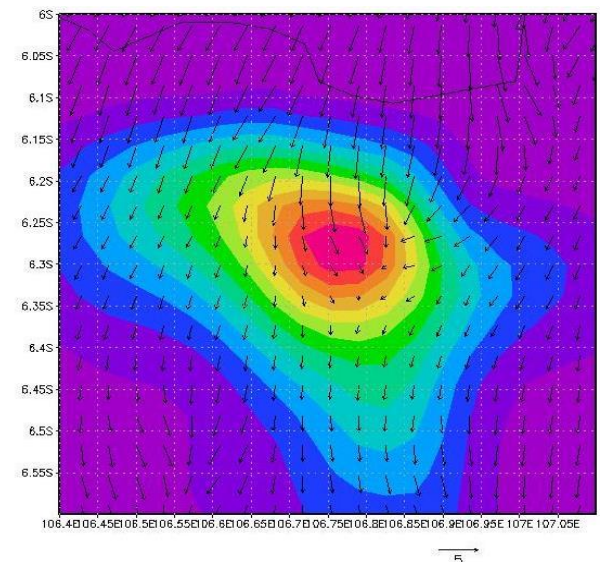

(a)

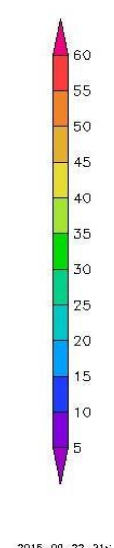

$2015-09-22-21:$

Data observasi DKI Jakarta juga menunjukkan pada malam hari konsentrasi $\mathrm{PM}_{10}$ tertinggi tercatat di stasiun pengamatan Kelapa Gading Jakarta Utara. Pusat kota senantiasa berpotensi menjadi wilayah yang terpapar pencemar dengan konsentrasi maksimum (Pasquill, 1974). Pada bulan Desember sebaran spasial konsentrasi $\mathrm{PM}_{10}$ hampir sama dengan bulan Agustus, tetapi bergeser ke arah Barat dibandingkan dengan bulan Agustus, yaitu di wilayah Jakarta Selatan hingga perbatasan Tangerang Selatan (Gambar 6). Berdasar pola angin, tampak di lokasi tersebut merupakan arah tujuan angin dari Utara juga dari Timur. Wilayah Timur Jakarta merupakan wilayah industri seperti Kawasan Cakung dan juga dari wilayah Bekasi, sehingga angin dari Timur berpotensi membawa zat pencemar. Hal ini didukung oleh penelitian Gupta dan Mohan (2013) bahwa konsentrasi PM $_{10}$ lokal dapat dipengaruhi oleh kontribusi long-range transport dari daerah lain di sekitarnya. Pada malam hari konsentrasi maksimum terbentuk di wilayah Tangerang Selatan serta Kabupaten Tangerang

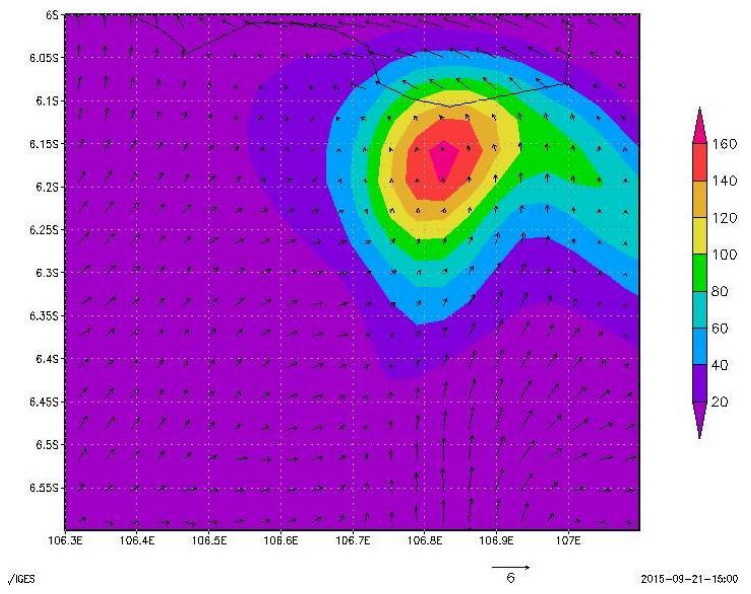

(b)

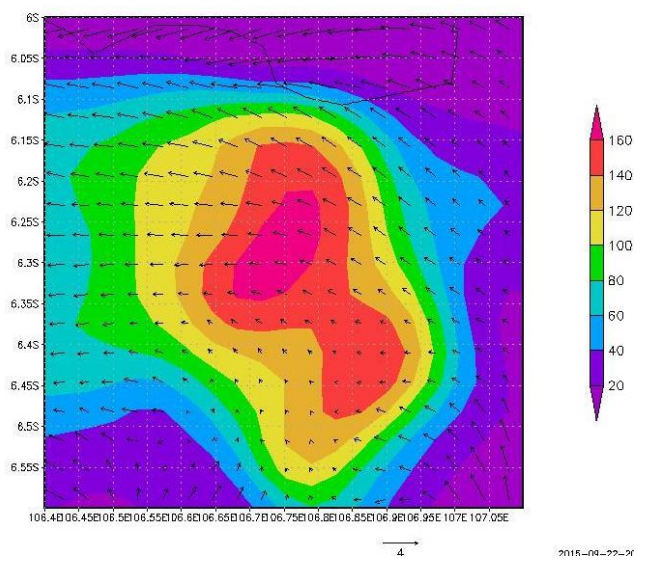

(B)

Gambar 6. Dispersi spasial $\mathrm{PM}_{10}$ bulan Desember 2014 pada (a) siang hari (11.00) dan (b) pagi hari (05.00). 


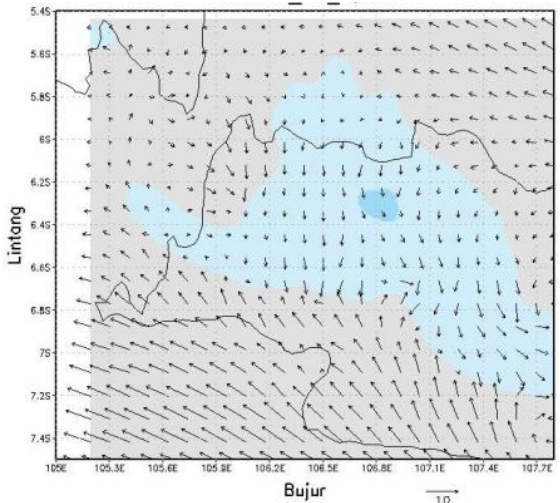

(a)

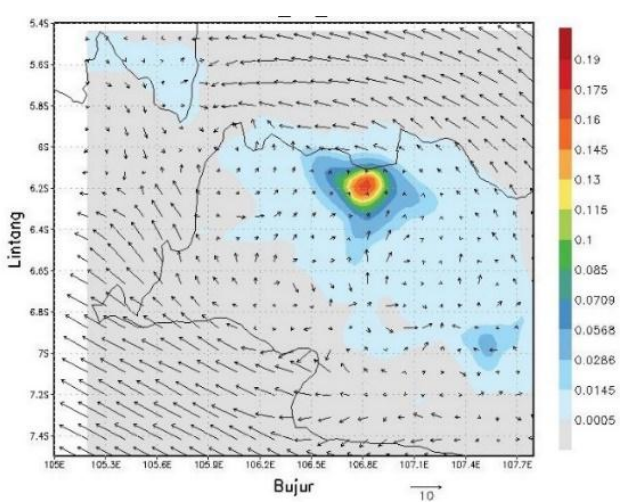

(b)

Gambar 7. Sebaran konsentrasi $\mathrm{SO}_{2}$ bulan (a) Agustus dan (b) Desember 2014.

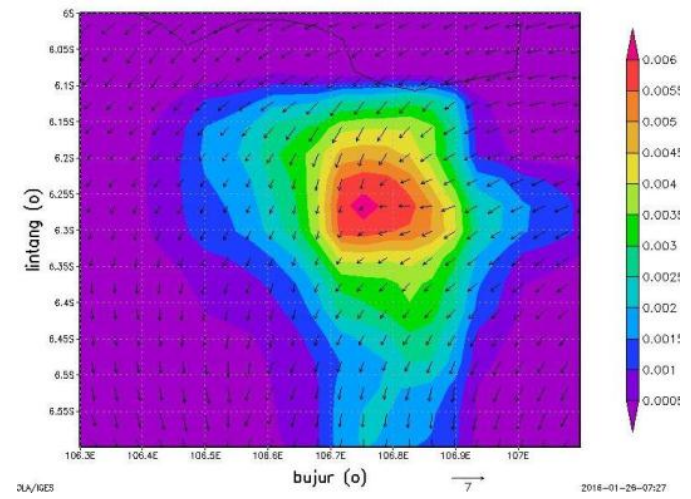

(a)

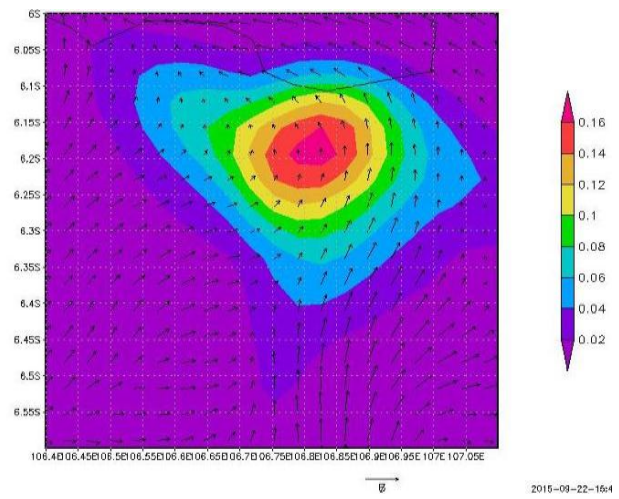

(b)

Gambar 8. Sebaran konsentrasi $\mathrm{SO}_{2}$ bulan Agustus 2104 pada (a) siang hari (11.00) dan (b), pagi hari (05.00).

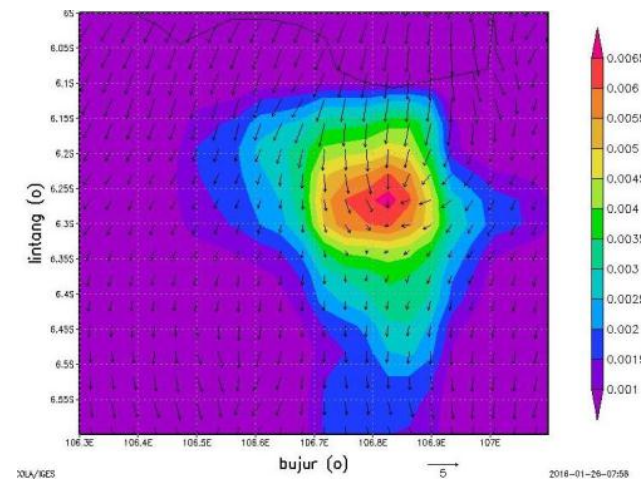

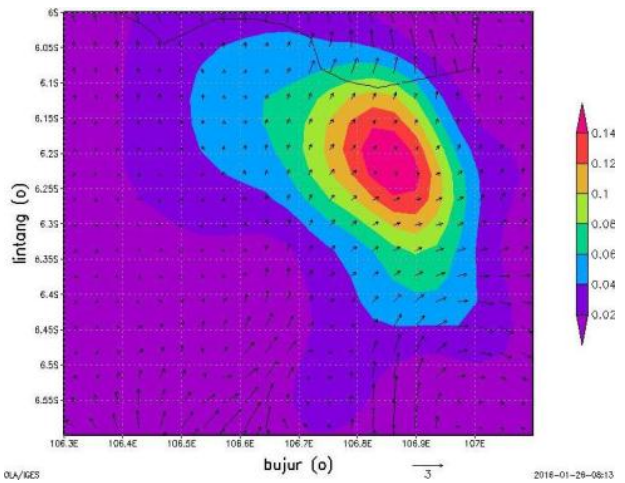

(b)

Gambar 9. Sebaran konsentrasi $\mathrm{SO}_{2}$ bulan Desember 2014 pada (a) siang hari (11.00) dan (b) pagi hari (05.00).

\section{Pola Sebaran Sulfurdioksida $\left(\mathrm{SO}_{2}\right)$}

Sebaran $\quad \mathrm{SO}_{2}$ menunjukkan konsentrasi maksimum pencemar terjadi malam hingga dini hari, dan umumnya konsentrasi tertinggi terjadi setelah pukul 02.00 WIB. Siang hari terutama sekitar tengah hari konsentrasi $\mathrm{SO}_{2}$ sangat rendah. DKI Jakarta dan Tangerang tetap menjadi wilayah yang berpotensi terpapar pencemar dengan konsentrasi maksimum (Gambar 7). Pola sebaran $\mathrm{SO}_{2}$ agak berbeda dengan sebaran $\mathrm{PM}_{10}$. Konsentrasi $\mathrm{SO}_{2}$ pola sebarannya tidak seluas $\mathrm{PM}_{10}$. Karakteristik $\mathrm{PM}_{10}$ tidak mudah bereaksi dan berubah menjadi pencemar lain, sehingga memungkinkan sebarannya meluas terbawa oleh angin. $\mathrm{SO}_{2}$ berupa gas yang ringan, dan bisa berubah secara kimiawi sehingga cepat menghilang dan menyebabkan cakupan wilayah dengan konsentrasi maksimumnya lebih sempit.

Pada bulan Agustus, siang hari konsentrasi maksimum terdapat di sekitar Jakarta Selatan, hingga ke perbatasan Tangerang Selatan. Malam hingga pagi hari, konsentrasi maksimum $\mathrm{SO}_{2}$ bergeser ke Jakarta Pusat (Gambar 8). Konsentrasi maksimum $\mathrm{SO}_{2}$ pada bulan Desember lebih bergeser kearah Barat dibandingkan bulan Agustus (Gambar 9). Dibandingkan dengan $\mathrm{PM}_{10}$, pusat konsentrasi $\mathrm{SO}_{2}$ juga lebih bergeser ke arah perbatasan Jakarta 
dan Tangerang atau Tangerang Selatan. Akumulasi $\mathrm{SO}_{2}$ di suatu tempat sangat berkaitan dengan sumber pencemar berupa industri dan atau sumber pencemar kendaraan-kendaraan besar yang menggunakan mesin diesel berbahan bakar solar. Umumnya kendaraan besar berkaitan dengan aktivitas industri, sehingga dalam hal ini kontribusi sumber industri pasti cukup tinggi, walaupun di sekitarnya tidak terdapat lokasi industri. Pencemar tersebut terbawa oleh angin dari wilayah lain, sehingga di wilayah tersebut mendapat tambahan $\mathrm{SO}_{2}$.

\section{KESIMPULAN}

Fluktuasi konsentrasi pencemar secara diurnal menunjukkan konsentrasi maksimum pada malam hari menjelang pagi, dan menurun menjelang siang dan sore hari, kecuali untuk $\mathrm{SO}_{2}$ ada peningkatan konsentrasi pagi menjelang siang, bertepatan dengan peningkatan volume kendaraan pada jam kerja.

Hasil analisis dispersi spasial menunjukkan bahwa konsentrasi maksimum $\mathrm{PM}_{10}$ dan $\mathrm{SO}_{2}$ berpotensi terjadi di wilayah DKI Jakarta terutama pada malam hari menjelang pagi, sedangkan siang hari konsentrasi maksimum bergeser ke arah Tangerang dan Tangerang Selatan.. Konsentrasi maksimum pada pagi hari berpotensi melampaui nilai baku mutu nasional 24 jam, baik untuk $\mathrm{PM}_{10}$ maupun $\mathrm{SO}_{2}$.

Daerah Jakarta Pusat dan Jakarta Utara menjadi daerah yang paling berpotensi terpapar pencemar udara dengan konsentrasi maksimum, terutama tengah malam menjelang pagi. Oleh karena itu siang hari konsentrasi maksimum pencemar cenderung di daerah perbatasan Jakarta dengan Tangerang Selatan hingga KabupatenTangerang. Pola angin BaratTimur mempengaruhi pola sebaran pencemar, dan keberadaan garis pantai juga mempengaruhi terakumulasinya pencemar di sekitar Jakarta Pusat.

\section{UCAPAN TERIMAKASIH}

Ucapan terima kasih disampaikan kepada Bapak Danang Eko Nuryanto dari Pusat Penelitian dan Pengembangan Badan Meteorologi Klimatologi dan Geofisika (BMKG) yang telah membantu dalam setting pemodelan WRFChem dan pihak BPLHD DKI serta BLH Kabupaten Tangerang yang telah membantu dalam penyediaan data observasi. Tulisan ini merupakan bagian dari disertasi Penulis, oleh karena itu terimakasih juga disampaikan kepada pihak Dirjen Dikti yang telah membantu beasiswa S3 (BPPDN) Penulis.

\section{DAFTAR PUSTAKA}

Anonim, 1998. Toxicological Profile for Sulfurdioxide. US Department of Health and Human Services, Georgia.

Anonim, 2001. Quantification of the Health Effects of Exposure to Air Pollution : Report of a WHO Working Group. European Centre for Environment and Health, World Health Organization, Bilthoven.

Anonim, 2006. Air Quality Guidelines for Particulate Matter, Ozone, Nitrogen dioxide and Sulfur dioxide Global Update 2005: Summary of Risk Assessment. World Health Organization, Geneva.

Anonim, 2014. Advanced Research WRF (ARW) version 3 Modeling System User's Guide. Mesoscale and Microscale Meteorology Division, National Center for Atmospheric Research, http://www.mmm.ucar.edu/wrf/users/.

Arifin dan Sutomo, A.H., 2003. Faal Paru Penduduk Desa Tarjun Sekitar Pabrik Semen Tiga Roda Kecamatan Kelumpang Selatani Kabupaten Kota Baru. Jurnal Manusia dan Lingkungan 10(1):1-9.

Bacarelli, A., Baretta, F., Chang, D., Xiao, Z., McCraken, J.P., Díaz, A., Bertazzi, P.A., Schwartz, J., Sheng, W., dan Lifang, H., 2011. Effects of Particulate Air Pollution on Blood Pressure in a Highly Exposed Population in Beijing, China : a Repeated-Measure Study. Environmental Health, 10:108

Baklanov, A., Schlünzen, K., Suppan, P., Baldasano, J, Brunner, D, Aksoyoglu, S., Carmichael, G., Douros, J., Flemming, J., Forkel, R., Galmarini, S., Gauss, M., Grell, G., Hirtl, M., Joffre, S., Jorba, O., Kaas, E., Kaasik, M., Kallos, G., Kong, X., Korsholm, U., Kurganskiy, A., Kushta, J., Lohmann, U., Mahura, A., Manders-Groot, A., Maurizi, A., Moussiopoulos, N., Rao, S.T., Savage, N., Seigneur, C., Sokhi, R.S., Solazzo, E., Solomos, S., Sørensen, B., Tsegas, G., Vignati, E., Vogel, B., dan Zhang, Y., 2014. Online Coupled Regional Meteorology Chemistry Models in Europe: Current Status and Prospects. Atmos. Chem. Phys., 14:317398.

Finn, D., Clawson, K.L., Carter, R.G., Rich, J.D., Biltoft, C., dan Leach, M., 2010. Analysis of Urban Atmosphere Plume Concentration Fluctuation. Boundary Layer Meteorol, 136:431-456.

Forkel, R., Balzarini, A., Baró, R., Curci, G., Jiménez-Guerrero., P, Hirtl, M,, Honzak, L., 
Lorenz, C., Im, U., Pérez, J.L., Pirovano, G., José, R.S., Tuccella, P., Werhahn, J., dan Žabkar, R., 2015. Analysis of the WRF-Chem contributions to AQMEII phase2 with respect to aerosol radiative feedbacks on meteorology and pollutant distribution. Atmospheric Environment 115:630-645.

Grell, G. dan Baklanov, A., 2011. Integrated Modeling for Forecasting Weather and Air Quality: A Call for Fully Coupled Approaches. Atmospheric Environment, 45:6845-6851.

Grell, G., Peckham, S.E., Schmitz, R., McKeen, S.A., Frost, G., Skamarock, W.C., dan Eder, B., 2005. Fully Coupled "Online" Chemistry within the WRF Model. Atmos. Environ. 39:6957-6976.

Gupta, M dan Mohan, M., 2013. Assessment of Contribution to $\mathrm{PM}_{10}$ Concentrations from Long Range Transport of Pollutants using WRF/Chem over a Subtropical Urban Airshed. Atmospheric Pollution Research, 4:405-410.

Hadiwidodo, M., dan Huboyo, H.S., 2006. Pola Penyebaran Gas $\mathrm{NO}_{2}$ di Udara Ambien Kawasan Utara Kota Semarang pada Musim Kemarau menggunakan Program ISCST3. Jurnal Presipitasi 1(1):19-25

Heriyanto, E., 2014. Kajian Model WRF/Chem untuk Analisis Polusi Perkotaan. Laporan Tahunan Hasil-hasil Kegiatan Puslitbang BMKG Tahun 2014. Badan Meteorologi Klimatologi dan Geofisika, Jakarta.

Liao, J., Wang, T., Wang, X., Xie, M., Jiang, Z., Huang, X., dan Zhu, J., 2014. Impacts of Different Urban Canopy Schemes in WRF/Chem on Regional Climate and Air Quality in Yangtze River Delta, China. Atmospheric Research 145-146 : 226-243.

Lippmann, M., dan Ito, K., 2006. Sulfur Dioxide. Air Quality Guidelines Global Update 2005: Particulate Matter, Ozone, Nitrogen Dioxide and Sulfur Dioxide. World Health Organization Regional Office for Europe, Copenhagen.

López-Cima, M.F., García-Pérez, J., Pérez-Gómez, B., Aragonés, N., López-Abente, G., Tardón,A., dan Pollán, 2011. Lung Cancer Risk and Pollution in an Industrial Region of Northern Spain : a Hospital-based Casecontrol Study. International Journal of Health Geographics 10:10

Nasstrom, J.S., Sugiyama, G., Leone, Jr. J.M., dan Ermak, D.L., 2000. A Real-time Atmospheric Dispersion Modeling System. $11^{\text {th }}$ Joint Conference on the Application of Air
Pollution Meteorology with the Air Waste Management Association, Long Beach, CA. January 9-14, 2000.

Oke, T.R., 1986. Boundary Layer Climates. Methuen \& Co. Ltd, London.

Orru, H., Teinemaa, E., Lai, T., Tamm, T., Kaasik, M., Kimmel, V., Kangur, K., Merisalu, E., dan Forsberg, B., 2009. Health Impact Assessment of Particulate Pollution in Tallinn using Fine Spatial Resolution and Modeling Techniques. Environmental Health, 8:7-15.

Pasquill, F., 1974. Atmospheric Diffusion: The Dispersion of Windborn Material from Industrial and other Sources. $2^{\text {nd }}$ ed. John Wiley \& Sons Ltd, New York.

Pernigotti, D., Rossa, A.M., Ferrario, M.E., Sansone. M., dan Benassi, A., 2007. Influence of ABL Stability on the Diurnal Cycle of $\mathrm{PM}_{10}$ Concentration: Illustration of the Potential of the New Veneto Network of MW-radiometers and SODAR. Meteorologische Zeitschrift, Fast Track. DOI: 10.1127/0941-2948/ 2007/0204.

Rahmawati, F., 2003. Aplikasi Model Dispersi Gauss untuk Menduga Pencemaran Udara di Kawasan Industri [tesis]. Program Pascasarjana, Institut Pertanian Bogor, Bogor.

Ranzi, A., Fano, V., Erspamer, L., Lauriola, P., Perucci ,C.A., dan Forastiere, F., 2011. Mortality and Morbidity Among People Living Close to Incinerators : a Cohort Study Based on Dispersion for Exposure Assessment. Environmental Health 10:22.

Ruhiyat, Y., 2009. Model Prediksi Distibusi Laju Penyebaran Sulfur Dioksida $\left(\mathrm{SO}_{2}\right)$ dan Debu dari Kawasan Industri, Disertasi, Program Pascasarjana. Institut Pertanian Bogor, Bogor.

Sansone, M., Bressan, M., Pernigotti, D., Rossa, A.M., Ferrario, M.E., dan Benassi, A., 2006. A Multiple Regression Approach to Forecasting $\mathrm{PM}_{10}$ Concentration in the City of Padua, Italy. Proc. Of The Int. Conf. On Urban Climate, Göteborg, 10-16 June 2006.

Stroh, E., Oudin, A., Gustafsson, S., Pilesjö, P., Harrie, L., Strömberg, U., dan Jakobsson, K., 2005. Are Associations Between Socioeconomic Characteristics and Exposure to Air Pollution a Question of Study Area Size? An Example from Scania, Sweden. International Journal of Health Geographics 4:30-42.

Tseng, C.Y., Huang, Y.C., Su, S.Y., Huang, J.Y., Lai, C.H., Lung, C.C, Ho, C.C., dan Liaw, Y.P., 2012. Cell Type Specificity of Female Lung Cancer Associated with Sulfur Dioxide from Air Pollutants in Taiwan: An Ecological Study. BMC Public Health, 12(4):1-8. 
Tucella, P., Curci, G., Visconti, G., Bessagnet, B., Menut, L., dan Park, R.J., 2012. Modelling of Gas and Aerosol with WRF/Chem over Europe : Evaluation and Sensitivity Study. Journal of Geophysical Research, 117: D03303.

Warlina, L., 2008. Model Dampak Pencemaran untuk Penyusunan Kebijakan Pengendalian Dioksin/Furan (Studi Kasus : Industri Logam Di Kawasan Cilegon), Disertasi. Program Pascasarjana. Institut Pertanian Bogor, Bogor. Yerramilli, A., Challa, V.S., Dodla, V.B.R., Myles, L., Pendergrass, W.R., Vogel, C.A., Tuluri, F.,
Baham, J.M., Hughes, R., Patrick, C., Young, J., dan Swanier, S., 2008. Simulation of Surface Ozon Pollution in the Central Gulf Coast Region during Summer Synoptic Condition using WRF/Chem Air Quality Model. Atmospheric Pollution Research, 3:55-71.

Zhang, Y., Dubey, M.K., Olsen, S.C., Zheng, J., dan Zhang, R., 2009. Comparison of WRFChem Simulations in Mexico City with Groundbased RAMA Measurements During the 2006 - MILAGRO. Atmos. Chem. Phys., 9:37733798. 